\title{
Traditional Climate and Environment Forecasting Based on Local Knowledge of Urug Societies in Bogor West Java
}

\author{
Bahagia $^{1 *}$, Fachrudin Majeri Mangunjaya $^{2}$, Endin Mujahidin $^{1}$, Rimun Wibowo $^{3}$ \\ ${ }^{1}$ Department of Islamic Education, Universitas Ibn Khaldun Bogor, Jalan KH Soleh Iskandar, Bogor 16162, Indonesia \\ ${ }^{2}$ Department Biology, Pascasarjana Universitas Nasional, Pasar Minggu Jakarta 12520, Indonesia \\ ${ }^{3}$ LPM Equator, Jalan Sindang Barang, Bogor 16117, Indonesia
}

Corresponding Author Email: bahagia@uika-bogor.ac.id

https://doi.org/10.18280/ijsdp.160714

Received: 16 July 2020

Accepted: 15 July 2021

\section{Keywords:}

community resilience, indigenous

knowledge, climate, traditional storage,

traditional of years, local paddy

\begin{abstract}
The aim of this research to find out about Indigenous of Knowledge Urug Community for forecasting climate and environment dynamic toward community resilience. The research method used is the ethnographic approach or cultural anthropology. Ethnography is sorts of qualitative research that need observation, documentary and interview in local societies. Ethnographic deal with discovers about description about culture including local knowledge, behaviour, cultural, ritual, traditional ceremonies, and language of Urug community. The selection of sample as informant exert purposive sampling technique. The result is probed meticulously through triangulation technique and triangulation sources. The result shows that the Indigenous community have implemented the sort of Traditional and calendar years with animals symbol for forecasting season and climate. The community can adapt season and climate dynamic and create community resilience for environment and climate. Besides that, there is the connection of planting local paddy to attaint community resilience including environmental change, cultural and social resilience.
\end{abstract}

\section{INTRODUCTION}

The climate change variables such as temperature and rainfall variation lead to increase in crop pest population and disease outbreaks as well as a flood [1]. Climate change increases the stress on food systems, making resilience among rural communities more difficult [2]. Immediately, human life confronts to vulnerable because lack of food can be resulted by numerous issues. Indigenous peoples have a role to play in responding to climate change [3]. Indigenous people can adapt and mitigate environment hardship as well as climate change. Even folklore and proverb are utilized for the transfer of knowledge [4]. Local knowledge comes from the community and tie base on cultural [5].

Local knowledge includes as a cumulative body of knowledge, practice, experience and observations or from spiritual teachings which were handed down from generation to generation [6]. Problems are resolved based on experiences accumulated through centuries of people-nature interactions [7]. Meanwhile, indigenous knowledge can create community resilience instead of individual resilience because indigenous knowledge is a concerted decision base on the community.

Indigenous knowledge is a source of resilience because when indigenous knowledge is integrated into socioecological systems, these have demonstrated the ability to deal with complexity and uncertainty [8]. Traditional Knowledge can enhance social and ecological resilience through maintaining the capacity of ecosystems to provide essential services over time [9]. For achieving social-ecological resilience must imply social-ecological systems strategies and adaptation [10]. Social-ecological systems are integrated complex adaptive systems in which social and ecological subsystems are coupled and interdependent, each a function of the other, expressed in a series of mutual feedback relationships [11]. Further social-ecological resilience is not always linked to adaptation, it includes the ability to transform with change. Transform development practice and to support capacities to deal with shocks and surprises [12]. The indigenous community can withstand to perturbance in climate, food shortages, and environmental change through numerous real action.

There is a connection between social-ecological and indigenous knowledge because local people have knowledge about the phenomena of nature for forecasting climate as well as the environment, use of local variables which have been experimented for combating climate variation, and knowledge have ensured for achieving food resilience. Indigenous knowledge observes natural phenomena including the behaviour of animals, insect, plants, the direction of the wind, sort of clouds for foretelling climate periods [13, 14]. Indigenous people who have knowledge related to climate and weather, as well as indigenous knowledge, have developed adaptation strategies for ensuring food security [15]. In other, As excessive fruiting of breadfruit and mandarin (Citrus spp) result in extreme weather [16].

In a community like Yoggu and Chietanga which are determined drought season when snails and chameleon egg hatch [17]. Another clue such as crickets and spiders becoming more active is also a sign rain [18]. In South Africa in Tambo district detect drying periods when the movement numerous animals such as locusts, snakes, cobra, butterflies and bees [19]. Typically in Indonesia, Indigenous people like Baduy to 
react resilience for the dynamic environment through the diversity of crops including rice, pumpkin, long bean, job's tear, sweet potato, hyacinth, maize, and cucumber [20].

Another way is to trade the type of fruits plan including Durio zibethinus Murr, and banana (Musa paradisiaca). Even Baduy people barre member of people to trade their paddy to market [21]. In this research will discover other indigenous community namely Urug community. Indigenous of Urug people dwell in Urug Bogor West Java Indonesia. Urug Indigenous knowledge has a crucial role in combating climate and environmental change for attaining community resilience like another traditional community in Indonesia. This community have an action for confronting disturbance such as climate variation and environment dynamics. (I have abolished about the concept of making handicrafts to increase income like reviewer sugest).

This research will not test again the previous research but try to trace another action for creating resilience base on the local community. There is numerous aspect of resilience will be investigated including how Urug people connect type traditional years in Urug people with animals clue for determining climate, season and life disturbances. The other is to investigate the relationship between social, cultural, ecology resiliences through preserving local paddy.

\section{METHODOLOGY}

The research about Indigenous Knowledge of Urug Community for combating environment and climate change toward Attaining community resilience exert ethnography with qualitative approach method. This research is conducted in Urug village, Sukajaya District, Bogor Regency West Java
Indonesia. Urug village is bordered by various villages, in the north, Urug village borders Harkat Jaya village, in the south by Kiara Sari village and Curug Bitung village, in the east by Nanggung Village and in the west by Cisarua and Pasir Madang village. The map location of this research can be viewed in Figure 1.

Ethnography is the study of social interaction and culture groups, whether these groups are defined as societies, communities, organizations or teams. Ethnographic knowledge is therefore a collaborative process in which the researcher is engaged in constructing a story alongside the participants. This requires both researcher and participants to think critically about what they wish to represent and is a valuable technique to foster introspection and critical consciousness [22]. This allows the researcher to contextualize what people say, thereby augmenting our understanding of how people describe what they behaviour.

Analysing what people say alongside what they do in practice can offer a richer understanding of the complex social phenomenon [23]. While qualitative research emphasizes understanding through closely examining people's words, actions and records rather than assigning mathematical symbols to these words, actions and records [24]. Qualitative research focuses on understanding a research query as a humanistic or idealistic approach [25]. Also, Ethnographic can be mentioned as fieldwork research where the researcher visits to field and objects for looking for complete information. To gather the sample exerts purposive sampling technique. There are two key person that conforms to this research such as Abah Ukat as the highest position in Urug people due to He is chief of this community. It can be enabled to explain profoundly about the purpose of this research.

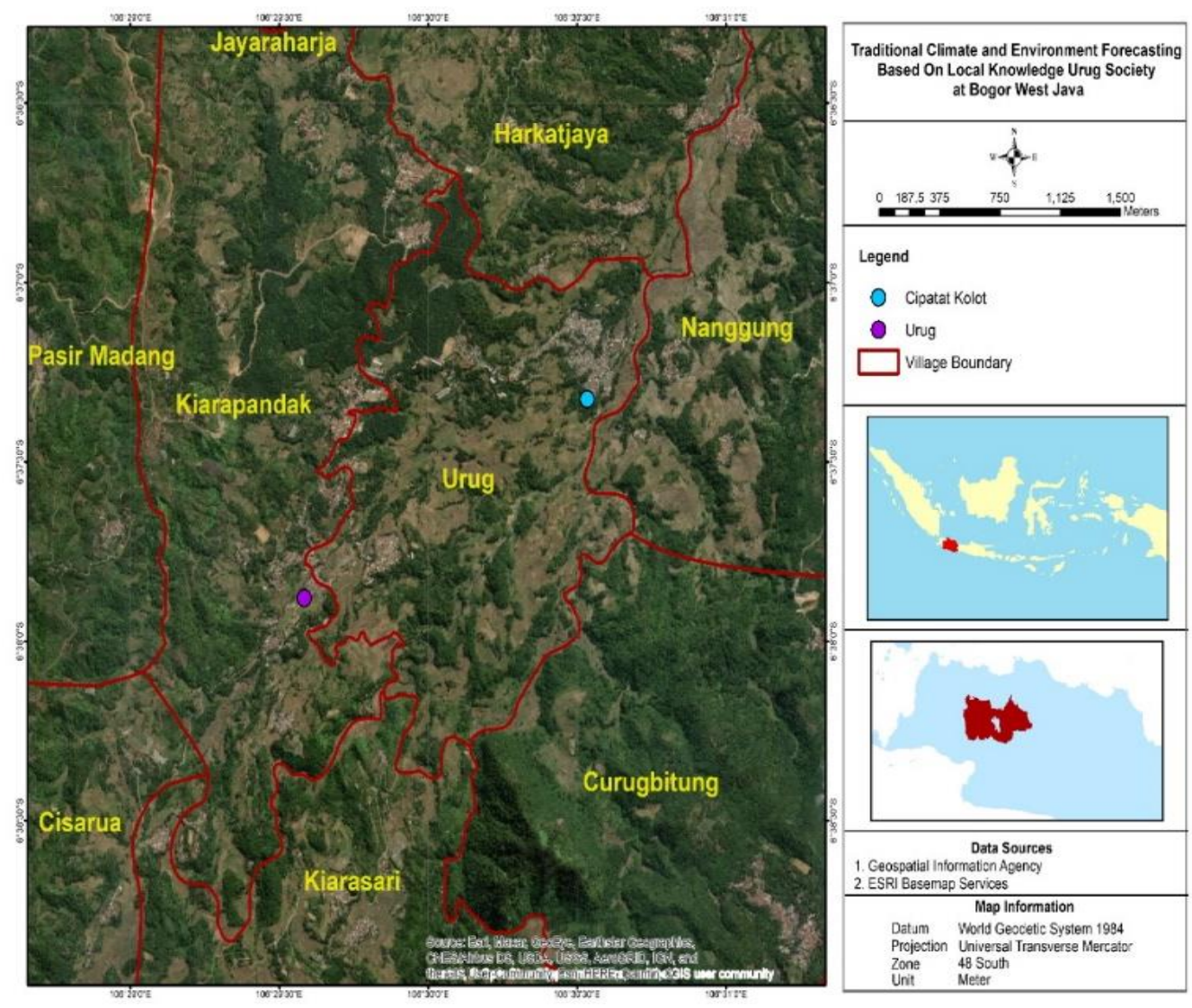

Figure 1. Map location of research (I also include map of research which I have not involved in previous paper) 
As a chief, Abah Ukat is widest knowledge compare to another person in Urug. While one determination of sample because the sample in the highest knowledge. Then, Abah Ukat recommends the other person who has the task of agriculture locally. In this research, there are several methods that researcher use including observation, In-depth interviews and documentation. Observation is implemented to envisage ritual cultural as well as the cultural ceremony of Urug societies including seren taun and sedekah ke bumi. Seren taun have recognized as a traditional ceremony before cultivating of paddies. Conversely, sedekah ka bumi can be mentioned ritual and ceremony of traditional societies after harvesting of paddies. The researcher includes in this ceremony to witness the event for gathering data naturally which researcher experience directly the ritual.

The researcher notes the value meaning of this ceremony. It can be bolstered by researcher settle in Urug societies environment to supervise the daily habit of local people. It makes the researcher comprehend comprehensively about life in a traditional community. Besides that, the researcher admits to the chief of societies to view several local paddies which have value cultural as well as the ritual ceremony of Urug Societies. Local paddies have been cultivated since Urug societies have inhabited the location. Meaning that planting local paddies and the traditional ceremony is heredity. Another method of use is In-depth interviews.

Another method for collecting data is In-depth interviews. In this section researcher interview both of the main sample to obtain data. The researcher uses mobile phone and recorder to save the interview data. Data are collected including the knowledge about traditional calendar and years which is linked to determine the drying and heavy drying season, rain and heavy rain season as well as climate. In this section, the researcher also obtains data about nature clue like name of animals as a clue for each traditional years which is connected to decide weather and climate. Even to obtain data about which years is hardship life for the people in the years because each year has impacted life and environment condition. Furthermore, the researcher tries to trace resilience societies for climate, life, and environment perturbances based on traditional year.

As result, it can be valuable to determine which years are fortunately and unworthy for societies when they release the activity in agriculture. The other is to have data related to local paddies which have climate, environment and cultural resilience. The other data is secondary data. Data will be collected from numerous sources of data including journal and book which are linked to indigenous knowledge. The results which are gathered from several methods such as observation, Interview and documentation must be analyzed by triangulation data. Thera are three sorts of triangulation including time, method, and sources. Triangulation of sources to search the data from other sources. While triangulation method mix numerous of method such as interview, observation and documenation. Morever, Triangulation time is checked the validata to responden in other time [26]. Analysis data in this research is conducted through the combinationa some of method such as observation, documentation and interview. Additionally, both of responden namely Abah Ukat and Abah Maman are triangulation of sources. The end of this triangulation both triangulation technique and sources can be convinced as valid data for this research.

\section{RESULT AND DISCUSSION}

\subsection{The sort of years base on indigenious people for forecasting season and climate}

Indigenous knowledge like Urug community have adopted local knowledge about climate and season knowledge through their forefather. Nature clue like animals behaviour is implied to forecast weather and season pattern through utilize as the symbol for each year. To determine the season and climate base on their experience. The indigenous person has observed the animals behaviour and connects to the dynamic of climate as well as season. The viewing of animal trait and where the animals' life is used to interpretative season each year. There are 8 kinds of year base on indigenous of Urug people namely Alief year, He, Jim Awal, Je, Dal, Be, Wau, and Jim Akhir. Each year are symbolized by the creature and interpreted to climate, eco-disaster, season, and life disturbance. The sort of years can be viewed in Table 1 .

Urug people measure and decide the name of years is radically different to modern people calendar in generally. The Urug people unknown about calendar because in Urug people mention it is as kolenyer. From the table can mention that there are 8 years in Urug People perception. Each year have 12 months. The overall of the month in 8 years in community compare to masehi calender is 96 month. For instance, there is 12 month in every year if we convert to masehi calender. The movement one year Alief to He is 12 month. The new years in Urug people is the strong difference to masehi calender. In modern people, new years will meet after human pass 12 months each year. On the contrary, Urug people experience new years after the position in jim akhir (8 years) from Alief years. Meaning that the movement old years to new years is about 8 years.

The fundamental of reading each year base on indigenous people linkage to location or habitat where of symbol life, style of symbol, and behaviour of symbol. Urug people have observed every year are differences typically for weather and season. Base on investigating and experience of the environment, Urug people exert biotic environment name like animals to indicate whether period will be swelter or wet season. There are 8 names of wild creature which is applied for indicating season, climate, and what will occur in each year including kerbau (Bubalus bubalis), jangek-jangek, orongorong (Gryllotalpa sp), titinggi (Trigoniulus Corallines), engkang-engkang (Geris sp), wedus (Capra aegagrus hircus), bancet (Occidozyga lima) and remis (Pilsbryoconcha exilis).

This animal is implied to determine that each year will be heavy rain and long drying time, as well as rain and drying periods, come at the same time. Indigenous people use this symbol because they believe that sign of nature is created by the hand of god's [27]. The usage of animals symbols for cultivating has conducted in Java farmer namely pranata mongso (Climate rules). In farming, Java farmer exerts symbol of plant, animals, and the change of season [28]. The usage of the symbol has a heavy connection to real-life experience who they have observed the situation of environment and life. When the people implement symbol to life, they convince that person can strive for any hurdle. Scientifically, animals are known to have instinctive capabilities of sensing and detecting subtle changes in environmental variables and anticipate different natural events including climatic and geological events, thereby changing their behaviours including reproduction, migration and feeding, to adapt to the expected 
changes [29]. Nature symbol in each year connects to behaviour in the life of a person. The appearing nest termes on the earth can lead to rainy periods as well as flies and gadflies attack paddy fields [30].

The wet season also can be indicated when red ant creates mounds (Formicidae sp) and black ant (Formicidae sp) cross sidewalk [31]. When appearing a large number of ant from their hole for collecting food can determine rainy season [32]. The finding previous research is similar to indigenous people of Urug where they use nature clue like animal behaviour to foretell climate as well as season. Despite the animals use in Urug societies is different kind with other animals in other are. In Urug people, animals are applicated as the symbol of years. Every animal symbol in the type of years has meaning to environment change, season and life disturbances. In order to predict the variation of climate, according to abah Ukat as leader of Urug reveal that in the first of the year in Urug societies are mentioned as Alief year with symbol Bubalus bubalis. In local people perspective like Urug societies, the character of animals like buffalo have connected water and this animal have trait that animals require much water. The kinds of this animal can't withstand without water. Even animal-like buffalo require mud pond as a place to liquid their body.

Urug societies connect it to determine the weather and season. It shows that rain comes to the environment but it is not heavy rainwater as well as the drying period is not hard in this year. The environment which is not hardy rain but there is rain and there is drying season can be categorized as the best years and season for a human to release their activity for surviving. In this year can be categorized as good years and the season for human activity despite the human must be cautious. However, the years and symbol have been encouraged by the person but the people must be followed local and culture policy. For example, when the person conducts the activity, the person must be suited with time or schedule. For instance, the people in Urug cultivate paddy one time in a year, when the person acts beyond the rules, the people can confront to hardship period although alif years is included best years compare to another year in local perspective. In these years, It can be worthy for local people because they derive prosperity because the obstacle can be overcome by them. As farmer cultivating their paddies in the field, they are triumph because in this year's water is adequate for planting but they don't experience scarcity of water for watering their paddy field.

In another local tribe also practice the behaviour of nature or bioindicator to release their activity. For example, when Senegalese Cowcow bird sing in the morning or anytime, rain season come to the environment [33]. It can be discovered in other societies like Batonga people in the Zambezi, when the lion visit the shrine and the frogs crocking, rain season come and time for cultivating the plants [34]. The emergence of termite as an indicator that it a good season and rain onset [35]. The appearing of ant and butterfly can indicate that it must be a good season and flying of ants as a clue that rain period appear [36]

Besides, when to observe the snakes move to mountain area indicate that it can good rain [37]. The second year of Urug namely He years. Another clue of nature use is insects like mikonikoni (dragonflies) and sharara/ishwa (flying termites) are regarded as good indicators of the imminence of rainfall, especially when they fly past a certain area in swarms [38]. In these years, Urug people will experience a drying period because of the symbol of life in the dry land. Thirdly year is Jim Awal. (Gryllotalpa sp) as a clue for thirdly years. The season in this years must be connected with where Gryllotalpa sp spend a lifetime each day.

Table 1. The sort of years and calender for forecasting climate and season as well as life situation

\begin{tabular}{cc}
\hline $\begin{array}{c}\text { Name } \\
\text { of } \\
\text { years }\end{array}$ & Symbol of years \\
& \\
Alief & Kerbau (Bubalus bubalis) \\
& \\
He & Jangek-Jangek/walang kecek \\
Jim & $\begin{array}{c}\text { Orong-orong/Anjing tanah } \\
\text { (Gryllotalpa sp) }\end{array}$ \\
Awal & \\
&
\end{tabular}

Je Titinggi (Trigoniulus Corallines)

Dal Wedus (Capra aegagrus hircus)

Be $\quad$ Engkang-Engkang (Geris sp)

Wau Bancet (Occidozyga lima)

Jim Haremis (Pilsbryoconcha exilis)
Meaning in climate, season, and life

In Urug people perception, this years is the best period for them. However, the person must be cautious because each person can experience the possibility of perturbance and hurdle. The most imperative is action must be suited to the time period. For example, planting season must observe where the constellation of kidang star. When Kidang have moved to east zonation, this time can be recommended for cultivating paddy instead of rising in east location.

The environment will dry because the habitat of jangek-jangek on the surface of the earth. In this years, the environment leads to dry season because of orong-orong animal life in a dry land. The length of the drying season is around 3-4 month.

The character of this animal is to move severe slowly and easy to scroll when the human touch body of this animal. The connection to life is a person can be unworthy when confronting to heavy disturbance. In these years, the life of people is a vulnerable situation. If people have activity, they must be cautious to run activities for life.

The behaviour of wedus is to dwell in the drying area rather than watery land. The habitat where wedus life connect to season namely drying season. For example, in 2017-2018 is wedus years in Urug people, the drying season was about 7-8 month.

In this years, the urug people convinced that the person will experience hardship situation again. It is connected behaviour of engkang-engkang. These animals settle on the surface of the watery ecosystem such as a river, lake, and wetland paddy. The behaviour of these animals look like severe tame to human, after nearing, animal fails to catch. Logically, As our paddy can grow fertility, the production of paddy will reach hight yield but people can fail to collect paddy yield due to similar to the behaviour of Engkang-engkang.

Bancet can life both in two types of habitat such as watery zonation and drying location. Despite this aminal enable to live in rice wetland but the animal will not stay until 24 hours. It can connect to the long term of swelter season and rainy period

Haremis imposible dwell in dry season, this animals dwell 24 hours in watery zonation. In this year, the people experience heavy rainy. 
The character of this animal is dwelling in dry land and never lived in the watery ecosystem. As consequence as, the habitat of Gryllotalpa sp in dryland link to drying period. Urug people like Abah Ukat uttered that the season has connected to where Gryllotalpa sp life. The finding has similar with previous research, emerging of swarms of grasshoppers to land can indicate dry season [39]. It is supported that when cricketers are observed on the ground, and as a spider has closed their nest, meaning that poor rain season occurred because spider hates the moisture environment [40].

Abah Ukat as leader convinces that in this years, the season must be swelter period around 3-4 month. In fourth years, the person must be careful when person initiate activity because this year is vulnerable in social life. It is linked to the trait of Titinggi that this animal runs slightly but easy to stop when the personal touch this animal. As this symbol drag to real life, the person has to be cautious because the person who releases activity can go down rapidly like the behaviour Trigoniulus Corallines. Another name of years is Dal with symbol of wedus.

Aah Ukat reveals that in this years, the environment will predict the drying season. In 2017-2018 can be involved as Dal years in Urug people, the season in this years is hardly drought because in those years people have experienced drying period about 7-8 month. It is connected to the symbol of years, Ovis Aries like life in dry land rather than in watery zonation. Ovis Aries hate to dwell in watery land because of this animal life in drying area instead of settling in moisture environment. Even wedus (Ovis Aries) must be serviced by shepherds because Ovis Aries can't gather meal naturally. Even Ovis aries can suffer from the ailment as the owner impel Ovis Aries in watery land. It indicates that the society in Urug use Ovis Aries based on the behaviour of Wedus which the animals enable to close the water. The impact is rain season unable to come in this years.

When cattle are calm and sleep very close to each other in a stable, refuses to go and graze on the nearest meadow, preferring to stay near the watering point, losing appetite for grass and salt, lack of interest in reproductive activities, and isolation from others from the herd to bull. Other droughtrelated indicators for livestock include weight loss on standing hair on the skin, defecating and urinating in a sitting position. It distinguishes to in Luganda societies where they use the animal's nature clue like movement and appearance of animals in temporary time like an insect for determining drying season [41]. The clue like the migration of animals also as a signal that it is drying season [42]. Another forecasting drying period can be observed through the sound of wild animals. When hearing loss sound of lion impact to drying period.

Conversely, as the heavy sound of lion indicates heavy rain. It similar when no singing of bird effect to rise drying period. On the contrary, If birds sing loudly, rain must become [43]. In other community of group, In Uganda, to forecast drying period exerts the migration of insects such as butterflies, red caterpillars, western honey bees, Apis mellifera Linnaeus (Hymenoptera: Apidae), bush crickets, and Ruspolia bailey Otte (Orthoptera: Tettigoniidae). The other years are Be years with symbol of years namely engkang-engkang (Aquarius remigis). The habitat of Aquarius remigis is in the river, swam area, wet rice paddy field, and lake. The character of this animal looks like severe tame for the person and close to human after human nearing to this animal, Aquarius remigis can move quickly and the people fail to capture.

The hardship life circumstances as a result as this symbol because Urug people believe there is a connection between the behaviour of Aquarius remigis as years symbol and life obstacle. Life perturbance in this section includes ecocatastrophe where the disaster can combat the farmer in this years. Besides that, insect attack is another life disturbance which the people can experience about it and effect to derive the adverse impact on life for people. Despite the people have conducted activity like agriculture suited with the time for cultivating but it can enable people to undergo hardship condition. If these years come to human, people must be cautious because the years is unfortunate. The farmer in this years will be dreadful because based on experience in this years, human has the burden to avoid life havoc. As Farmer can be combated by season, insect, and flooding.

Meaning that some societies still use animals to foretell bad condition in forthcoming. Furthermore, bancet (Occidozyga lima) or small frog is pictured for wau years. The location of life Occidozyga lima is two locations both in wetland and dry land. In this years, drying season and rainy period will come to the environment because Occidozyga lima can dwell in two locations. However, Occidozyga lima can't live 24 hours in watery land like wet paddy filed, in a bank of the river, and lake. The biggest time is allocated in the dry land. In real fact environment, people action must be careful. If a person is entrepreneurship, the people can experience unworthy as well as impact to reduce funding as capital without garnish outcome. The last type of years name of Urug people is Jim Akhir with symbol Remis (Pilsbryoconcha exilis). In this years, traditional people fully convinced that the season will be the wet season for the long term as well as the storm and heavy rain season.

This animals unable to live in the dry season but remis settle in the watery ecosystem for 24 hours. In this years, the environment will abandon water because heavy rain season can't be halted due to the habitat of Remis fully in a wet environment. The impact in this years is human can suffer from eco-disaster like flooding because rainwater finds abundant in the environment. Even water can find anywhere and people impossible experience lack of water in these years. In other location, the attitude of birds as symbol heavy rain which impacts to flooding. In Zunheboto district, society predicts heavy rain which results in flooding through Flood the height of the birds' nests such as tailed wren babbler (Spelaeornis chocolatinus) and rusty-capped fulvetta (Alcippe dubia). Heavy rain and flooding combat environment when the bird builds the nest at the crown of trees which far from the body of water. On the contrary, the rain will halt as the bird construct their nest close to the ground [44].

Quechua and Aymara ethnic groups in Bolivia, people observed, for example, the location of the eggs of the leuque leuque (Vanellus resplendens, Andean lapwing) or the flowering patterns of Berberis commutata to predict the abundance of rain [45]. It is supported by another clue of nature like in Zimbabwe typically in Domboshawa community observe spider creating webs and appearing density spider population can be heavy wet season or rain hardly [46]. In Mizoram, northeastern India where crickets bring new soil out from the hole in rain season, it results in heavy rain can't be halted [47]. There is a similar finding where the other researchers have discovered that bioindicator like animals is used as a clue to predict rainy season. Despite among of finding exert different animal for deciding the season. Traditional years and calendar which contain numerous of clue and guider for constraining to climate and environment 
stressor.

Calendar and years based on Urug societies knowledge as information about life obstacle including the kinds of season and climate. Directly, it can attain resilience communities to face life disturbances because can pass the vulnerability. Society more resilience to climate change when they have recognized the condition in forthcoming through their experience before it occurs. If cultural and traditional about it losing, it impacts to jump the level of vulnerability of the community. The cultural value of Urug which have practised it heredity can tackle disturbances in life. Indigenous peoples have long maintained two positions: first, that their homelands are being transformed irreversibly by climate change, and second, that they have unique contributions to make towards climate decision-making due to their extensive experiential knowledge [48]. It has been adapted and observed by their forefather in previous time to complete the information.

The usage of the symbol in each year base on their experience for confronting variation of dynamic environment and climate. Behalf of this, people in Urug can create a map of years or calendar base on the environment. The calendar of Urug people can be useful for reacting the best adaptation and mitigation of season and climate as well as other life challenges. It can enable the community to reduce the risk of climate and season. The meaning of the character of the symbol is not knowledge accidentally but the knowledge has related to the experiment of life, learning and action and observe the changing in the environment for long periods.

Directly, as the person knows to act for combating climate, it can create community resiliences for facing life disturbances due to they can foretell the occurrence occurs in next time future. It can be categorized as the ability to anticipate, absorb, accommodate, or recover from climate change [49]. Resilience for facing climate and environmental change can be attained because Urug societies have predicted season and life condition in forthcoming before the perturbances occur. Urug people can mitigate and adapt climate through their calendar of the year including Urug people can predict the proper year when the first year namely Alief.

People undergo this year's impact to react to triumph in life. For example, in this years can be mentioned as the best year for agricultural production. Farming activity which is released in this year's impact to produce abandon of yield. It must be bolstered that in this years, the rain is not hard and slight drying. Both of season comes but it is not treacherous for human. In second years, the season must be drying. It leads to the farmer can response back the situation through differing cultivating of paddies because it lack of water in the vicinity of the environment. As a person still overlook, the people require to adapt through providing water by way of irrigation. Another value is to anticipate the human from a shortage of water where the societies require to fulfil basic need like water. This guide can assist the people from avoiding scarcity of liquid. Meanwhile in thirdly years, drying period continue but the long periods of drying can be 3-4 four months. In this years, people still experience drying time but it more peril rather than previous years. It needs people more cautious because the drying can be more extreme in these years. The natural phenomena like this can attain resilience to confront environment obstacle because the people have prefered food, water, and other life sources to adapt to the situation.

It distinguishes to fourth of years where this year can be categorized as sorts of cautiousness years. There are some reason about this including unstable clime can be an adverse impact on people who they fail to cultivate paddies. Despite Urug societies have separated sorts of years and calender based on environment and experience, catastrophe may have come without prediction. The disaster also combats the people life quickly and hardly so the human doesn't have opted that they must be unfortunately in this period. Another example is the human effort hardly to produce paddies in the field based on cultural and local knowledge but it can be unsuccessfully because there are unpredicted disturbances like insect attack. It similar to another endeavour of a person like the people become entrepreneurship, in this year they must stay on alert because there is unpredicted event can strike the people. Based on this year, Urug society safeguard like anticipate action in agriculture and other behaviour which is out of farming activity. Another year which impacts to human life is Dal years.

The drying period is severe hardly in this time because drying occurs more than 7 months or 8 months. It similar to when Wau years come, the drying time is long-lasting in this time. It refers to vanish the water and water spring can unfunction and halt. Peasant can't pursue the production for staple food like rice and the water for irrigating can be declined. Based on the adverse impact, the circumstance in this years salvages human life because they increase their capacity to reduce the issue through they save the food. The basic fundamental of people in Urug, they hate to trade their paddies and rice. They only save it for eating. It makes them save from the perturbances life in Dal years. After passing the long swelter season. other years which is a peril for human are Be and jim akhir years. In be years, the human confronts to numerous life perturbances including flooding, drying, catastrophe, and other issues like ailment or disease as well as failure in some business. The circumstances have been recorded by people by observing each year, it attains resilience because they have a strategy to overcome this issues like they adopt more than livelihood sources as they work in agriculture for production basic food like rice but they also become vendor like trade fish in the traditional market and combine fish and rice when they planting in the field. In this action, they can obtain fortune from fishing and rice as a strategy for anticipating climate and environment perturbances.

\subsection{Climate and culture resilience in local paddies}

Local paddies have been protected by Urug societies amid the state of art in agriculture. Local paddies like Sri Kuning and Raja West have been cultivated by their forefather. It conserves and continues this variety of paddies in Urug societies. The behaviours pursue to a recent generation which the generation still farm local paddies. Meaning that the tradition for preserving local paddies genetic continue nowaday. The paddies can be categorized as long ages of paddies because the paddies yield can be harvested 6-7 month. The paddies have adapted for environment and climate because the paddies are planted since there is their forefather in Urug village. Despite the local paddy is longer for a time in production but it can abolish emission through resting land for letting the plant grow naturally. There is time for letting land where the people will not cultivate paddy and another kind of plants including small trees and bushes. Meanwhile, plantlike grass can absorb emission like carbon dioxide as well as the production of oxygens. The ages of local paddy variety are around 6-7 month. There is about 5-6 month in a year where the people have implied this action to ensure the land free from agriculture activity. 
When the time for planting season has appeared, the farmer doesn't require to applicate more an-organic fertilizer due to soil fertility have been ameliorated by nature naturally. The land will be abandoned by fertility naturally due to vegetation grow naturally before cultivating land again for farming. Farmer utilizes this fertilizer just for complementary which land severe lack of fertility. The adverse impact to applicate factory fertilizer can reduce the production a half in years, disturb nature mechanical, kill flora and fauna which is worth for maintenance of soil nutrient [50]. As a result, as, the sustainability of production rate can reach each year without plummeting of paddy production. However, in Abah Ukat perception, when people applicate factory fertilizer to land, soil can be refined the rate of fertility but the fertility due to adopt technology instead of improving soil nutrient naturally.

They are numerous demerits of intensive farming including it contributes to producing emission as well as replaced natural control process and resources, rendering them more vulnerable [51]. The other impact is to vanish local genetic variety convert to the number of modern varieties [52]. In Urug people, the person still persistence to farm local variety including ketan gadok, item, sri kuning, and raja wesi as local paddy variety. Meanwhile, the persistence principle is the primary measure of sustainability whereas an argument for resilience further requires demonstration that there were perturbations to which the system had to respond.

In one side, the usage of local varieties is a way for combating climate because local biodiversity like paddy has adapted for long periods and environment change. The paddy has been cultivated since the Urug people have been born.

Local variety also better adapted to the environment, better survive, produce high yields of phytochemically rich foods with fewer inputs including water, fertilization, and pest and disease control [53]. The local people also have learned from the dynamic of climate uncertainties so local people conserve local plant and animals [54]. Local people hesitate to adopt the other varieties because still unknown the advantage of the type of varieties. The other is there is a linkage between local paddy and cultural like traditional ritual and ceremonial.

\section{CONCLUSION}

The result of research can be concluded including indigenous Urug people divide years into 8 years. Urug people wield animals as symbol each year. To forecast season and climate, Urug people exert behaviour and habitat of the animal as a clue for every year. As animals as symbol settle in the watery ecosystem like a river, lake and wetland, rainy season or wet periods will occur. Conversely, when the trait of animals as symbol allocate time for life in drying land, drying period or environment can be swelter. Furthermore, If the animal can dwell both wetland and drying land, both of the drying periods and the rainy time comes to the environment. Based on traditional years, the fortunes years is Alief. Urug society experience a drying period in He but swelter period is not hard because the rain still come. In Jim awal, drying time come again but society experience 3-4 four months in this years for lack of water.

Contrary, in Dal years, Urug societies predict that environment confronts to heady swelter because it is long drying schedule. Besides, the same season occurs again in Wau years where the environment is faced to drying period. Beside, Urug societies also believe that in Be years, people must be cautious because the people can face some obstacle including life failure, eco-catastrophe, flooding, and unsuccessful activity. The determination of environment, climate, and life perturbances react resilience based on observing from years-to years. They attain resilience for confronting life perturbances because they have recognized the occurrence in forthcoming. The other is indigenous knowledge cultivate local paddy persistently.

Lastly, Urug societies cultivate local paddies as a way to preserve local paddies and culture. Local paddies have culture value because the forefather has propagated it for a long period It is continued and embedded to nowadays generation to pursue tradition and habit. Local paddies can reduce emission because local societies have a habit to cultivate local paddies only one time in years. It makes the soil avoid damaged and reduce in using fertilizer. The impact is environment can clean from emission. It must be bolstered that local paddies have adapted for some environment and climate stressors because it has cultivated and experience in some condition. It shows that local paddies are more powerful to environment pressure like heavy drying and rain.

This research have several advantage including the research have connected between indigenious knowledge which this research is regret amid globalisation and expanding technology, this research try to contibute for adaptation of climate to attaint resilience societies based on local knowledge. It is a great contribution to goverment which they focus on technology like using equipment for predicting climate through meteorological and climate agency. Meaning that, they need to mix local technology with modern tool for adapting climate dynamic. However, this research have weakness like local knowledge based on local people. It need to discover whether this research can be adopted in another location nationally and internationally.

\section{ACKNOWLEDGMENT}

It is worthy comments from reviewer for us to refine our article. The finding in this research is the expression and conclusion based on author perspective. It doesn't link to the organization where the author work or any another institution have bolstered for providing this research paper.

\section{REFERENCES}

[1] Amare, Z.Y. (2018). Indigenous knowledge of rural communities for combating climate change impacts in west central ethiopia. J. Agric. Ext., 22(1): 181-195. https://doi.org/10.4314/jae.v22i1.16

[2] Dooley, K.E., Grady Roberts, T. (2020). Agricultural education and extension curriculum innovation: the nexus of climate change, food security, and community resilience. J. Agric. Educ. Ext., 26(1): 1-3. https://doi.org/10.1080/1389224X.2019.1703507

[3] Ramos-Castillo, A., Castellanos, E.J., Galloway McLean, K. (2017). Indigenous peoples, local communities and climate change mitigation. Clim. Change, 140(1): 1-4. https://doi.org/10.1007/s10584-016-1873-0

[4] Mosissa, R., Jimma, W., Bekele, R. (2017). Knowledge management strategy for indigenous knowledge on land use and agricultural development in Western Ethiopia. Univers. J. Agric. Res., 5(1): 18-26. 
https://doi.org/10.13189/ujar.2017.050103

[5] Ristroph, E.B. (2019). Addressing climate change vulnerability in alaska native villages through indigenous community knowledge. Sociol. Study, 9(1). https://doi.org/10.17265/2159-5526/2019.01.001

[6] Berkes, F. (2017). Environmental governance for the anthropocene? Social-ecological systems, resilience, and collaborative learning. Sustain., 9(7). https://doi.org/10.3390/su9071232

[7] Hill, R., Adem, Ç., Valangui, W., et al. (2019). Working with indigenous, local and scientific knowledge in assessments of nature and nature's linkages with people. Curr. Opin. Environ. Sustain., 43: 8-20. https://doi.org/10.1016/j.cosust.2019.12.006

[8] Rahman, A., Sakurai, A., Munadi, K. (2017). Indigenous knowledge management to enhance community resilience to tsunami risk: Lessons learned from Smong traditions in Simeulue island, Indonesia. IOP Conf. Ser. Earth Environ. Sci., 56(1). https://doi.org/10.1088/1755$1315 / 56 / 1 / 012018$

[9] Gómez-Baggethun, E., Corbera, E., Reyes-García, V. (2013). Traditional ecological knowledge and global environmental change: Research findings and policy implications. Ecol. Soc., 18(4): 1-12. https://doi.org/10.5751/ES-06288-180472

[10] Mulrennan, M.E., Bussières, V. (2018). Socialecological resilience in indigenous coastal edge contexts. Ecol. Soc., 23(3). https://doi.org/10.5751/ES-10341230318

[11] Folke, C., Biggs, R., Norström, A.V., Reyers, B., Rockström, J. (2016). Social-ecological resilience and biosphere-based sustainability science. Ecol. Soc., 21(3): 41. https://doi.org/10.5751/ES-08748-210341

[12] Reyers, B., Folke, C., Moore, M.L., Biggs, R., Galaz, V. (2018). Social-ecological systems insights for navigating the dynamics of the anthropocene. Annu. Rev. Environ. Resour., 43: 267-289. https://doi.org/10.1146/annurevenviron-110615-085349

[13] Radeny, M., Desalegn, A., Mubiru, D., Kyazze, F., Mahoo, H., Recha, J., Kimeli, P., Solomon, D. (2019). Indigenous knowledge for seasonal weather and climate forecasting across East Africa. Clim. Change, 156(4): 509-526. https://doi.org/10.1007/s10584-019-02476-9

[14] Kidemu, M., Gebreyesus, M., Semere, M., Worku, A., Anjulo, A. (2020). Traditional ecological knowledge for climate change assessment and rainfall prediction: A case of Adami Tulu Jido Kombolcha District, Oromia Region, Ethiopia. Int. J. Nat. Resour. Ecol. Manag., 5(2): 43. https://doi.org/10.11648/j.ijnrem.20200502.12

[15] Lam, S., Dodd, W., Skinner, K., et al. (2019). Community-based monitoring of Indigenous food security in a changing climate: Global trends and future directions. Environ. Res. Lett., 14(7): 073002. https://doi.org/10.1088/1748-9326/ab13e4

[16] Janif, S.Z., Nunn, P.D., Geraghty, P., Aalbersberg, W., Thomas, F.R., Camailakeba, M. (2016). Value of traditional oral narratives in building climate-change resilience: Insights from rural communities in Fiji. Ecol. Soc., 21(2). https://doi.org/10.5751/ES-08100-210207

[17] Ngwese, N.M., Saito, O., Sato, A., Boafo, Y.A., Jasaw, G. (2018). Traditional and local knowledge practices for disaster risk reduction in Northern Ghana. Sustain., 10(3): 825. https://doi.org/10.3390/su10030825

[18] Ubisi, N.R., Kolanisi, U., Jiri, O. (2020). The role of indigenous knowledge systems in rural smallholder farmers' response to climate change: Case study of nkomazi local municipality, Mpumalanga, South Africa. J. Asian Afr. Stud., 55(2): 273-284. https://doi.org/10.1177/0021909619874824.

[19] Muyambo, F., Bahta, Y.T., Jordaan, A.J. (2017). The role of indigenous knowledge in drought risk reduction: A case of communal farmers in South Africa. Jamba J. Disaster Risk Stud., $\quad$ 9(1): https://doi.org/10.4102/jamba.v9i1.420

[20] Iskandar, J., Iskandar, B.S. (2016). Resilience of Baduy traditional agro-forestry systems in responses to environmental and socio-economic changes. Journal of Indonesian Natural History, 4(1): 19-24.

[21] Iskandar, J., Iskandar, B.S. (2017). Kearifan ekologi orang baduy dalam konservasi padi dengan 'Sistem Leuit. $\begin{array}{lll}\text { J. } & \text { Biodjati, } & \text { 2(1): }\end{array}$ https://doi.org/10.15575/biodjati.v2i1.1289

[22] Bell, S.A., Aggleton, P. (2012). Integrating ethnographic principles in ngo monitoring and impact evaluation. J. Int. Dev., 24(6): 795-807. https://doi.org/10.1002/jid.2868

[23] Webster, F., Rice, K. (2019). Conducting ethnography in primary care. Fam. Pract., 36(4): 523-525. https://doi.org/10.1093/fampra/cmz007

[24] Omona, J. (2013). Sampling in qualitative research: improving the quality of research outcomes in higher education. Makerere J. High. Educ., 4(2): 169-185. https://doi.org/10.4314/majohe.v4i2.4

[25] Babu, A., Maiya, A., Shah, P., Veluswamy, S. (2013). Clinical trial registration in physiotherapy research. Perspect. Clin. Res., 4(3): 191. https://doi.org/10.4103/2229-3485.115387

[26] Helaluddin, Wijaya, H. (2019). Qualitative Data Analysis A Review of Theory and Practice. 148.

[27] Elia, E.F. (2014). Indigenous Knowledge use in seasonal weather forecasting in Tanzania: The case of semi-arid central Tanzania. Indig. Knowl. use Seas. Weather Forecast. Tanzania case semi-arid Cent. Tanzania, 80(1): 18-27. https://doi.org/10.7553/80-1-180

[28] Anazifa, R.D. (2016). Pemanfaatan Sains tradisional jawa sistem Pronotomongso melalui kajian etnosains sebagai bahan ajar biologi. Prosiding Semnas Pend IPA Pascasarjana UM, 1: 832-838.

[29] Balehegn, M., Balehey, S., Fu, C., Liang, W. (2019). Indigenous weather and climate forecasting knowledge among Afar pastoralists of north eastern Ethiopia: Role in adaptation to weather and climate variability. Pastoralism, 9(1). https://doi.org/10.1186/s13570-0190143-y

[30] Phu, P. (2019). Use of indigenous knowledge to adapt with climate change: A case study in An Giang province, in the Mekong Delta, Viet Nam. Am. J. Biomed. Sci. Res., 1(1): https://doi.org/10.34297/ajbsr.2019.01.000506

[31] Rivero-Romero, A.D., Moreno-Calles, A.I., Casas, A., Castillo, A., Camou-Guerrero, A. (2016). Traditional climate knowledge: A case study in a peasant community of Tlaxcala, Mexico. J. Ethnobiol. Ethnomed., 12(1): 111. https://doi.org/10.1186/s13002-016-0105-z

[32] Manyanhaire, I.O., Chitura, M. (2015). Integrating indigenous knowledge systems into climate change interpretation: Perspectives relevant to zimbabwe. Greener J. Educ. Res., 5(2): 027-036. https://doi.org/10.15580/gjer.2015.2.012715022 
[33] Tume, S.J.P., Kimengsi, J.N., Fogwe, Z.N. (2019). Indigenous knowledge and farmer perceptions of climate and ecological changes in the bamenda highlands of cameroon: Insights from the bui plateau. Climate, 7(12). https://doi.org/10.3390/cli7120138

[34] Siambombe, A., Mutale, Q., Muzingili, T. (2018). Indigenous knowledge systems: A synthesis of batonga people's traditional knowledge on weather dynamism. African J. Soc. Work, 8(2): 46-54.

[35] Pareek, A., Trivedi, P.C. (2011). Cultural values and indigenous knowledge of climate change and disaster prediction in Rajasthan, India. Indian J. Tradit. Knowl., 10(1): 183-189.

[36] Chang'a, L., Yanda, P., Ngana, J. (2010). Indigenous knowledge in seasonal rainfall prediction in Tanzania: A case of the South-western Highland of Tanzania climate variability and its impacts in tanzania view project. $\mathrm{J}$. Geogr. Reg. $\quad$ Plan., 3: 66-72. http://www.academicjournals.org/JGRP.

[37] Zuma-Netshiukhwi, G., Stigter, K., Walker, S. (2013). Use of traditional weather/climate knowledge by farmers in the South-Western free State of South Africa: Agrometeorological learning by scientists. Atmosphere (Basel)., 4(4): 383-410. https://doi.org/10.3390/atmos4040383

[38] Muguti, T., Maposa, R.S. (2012). Indigenous Weather Forecasting: A Phenomenological Study Engaging the Shona of Zimbabwe. J. Pan African Stud., 4(9): 102.

[39] Ju, C. (2018). Relevance of indigenous knowledge in weather and climate forecast for planning farm activities by farmers in Imo State, Nigeria. Agric. Res. Technol. $\begin{array}{lll}\text { Open Access } & \text { J., }\end{array}$ https://doi.org/10.19080/artoaj.2018.19.556082

[40] Enock, C.M. (2013). Indigenous knowledge systems and modern weather forecasting: Exploring the linkages. J. Agric. Sustain., 2(1): 98-141.

[41] Okonya, J.S., Kroschel, J. (2013). Indigenous knowledge of seasonal weather forecasting: A case study in six regions of Uganda. Agric. Sci., 4(12): 641-648. https://doi.org/10.4236/as.2013.412086

[42] Kagunyu, A., Wandibba, S., Wanjohi, J.G. (2016). The use of indigenous climate forecasting methods by the pastoralists of Northern Kenya. Pastoralism, 6(1). https://doi.org/10.1186/s13570-016-0054-0

[43] Soropa, G., Gwatibaya, S., Musiyiwa, K., Rusere, F., Mavima, G.A., Kasasa, P. (2015). Indigenous knowledge system weather forecasts as a climate change adaptation strategy in smallholder farming systems of Zimbabwe: Case study of Murehwa, Tsholotsho and Chiredzi districts. African J. Agric. Res., 10(10): 1067-1075. https://doi.org/10.5897/ajar2013.7205

[44] Sumi, A. (2018). Birds as bioindicators of traditional weather forecasting among the sumi tribe of Nagaland, India. Asian J. Environ. Ecol., 7(4): 1-7. https://doi.org/10.9734/ajee/2018/45208

[45] Boillat, S., Berkes, F. (2013). Perception and interpretation of climate change among quechua farmers of bolivia. Ecol. Soc., 18(4): 21.

[46] Tanyanyiwa, V.I. (2018). Weather forecasting using local traditional knowledge (LTK) in the midst of climate change in domboshawa, zimbabwe. Clim. Chang. Manag., 1-20. https://doi.org/10.1007/978-3-319-700663_1

[47] Chinlampianga, M. (2011). Traditional knowledge, weather prediction and bioindicators: A case study in Mizoram, Northeastern India. Indian J. Tradit. Knowl., 10(1): 207-211.

[48] Nakashima, J.T., McLean, D., Thulstrup K.G., , H. D., Ramos Castillo, A., Rubis, J.T. (2013). Weathering uncertainty: Traditional knowledge for climate change assessment and adaptation. United Nations Educational, Scientific and Cultural Organization.

[49] Douxchamps, S., Debevec, L., Giordano, M., Barron, J. (2017). Monitoring and evaluation of climate resilience for agricultural development - A review of currently available tools. World Dev. Perspect., 5: 10-23. https://doi.org/10.1016/j.wdp.2017.02.001

[50] Briggs, J., Moyo, B. (2012). The resilience of indigenous knowledge in small-scale African Agriculture: Key drivers. Scottish Geogr. J., 128(1): 64-80. https://doi.org/10.1080/14702541.2012.694703

[51] Kughur, P.G., Audu, O. (2015). Effects of intensive agricultural production on the environment in Benue State, Nigeria. IOSR J. Agric. Vet. Sci. Ver. I, 8(8): 2319-2372. https://doi.org/10.9790/2380-08810711

[52] Reynolds, T.W., Waddington, S.R., Anderson, C.L., Chew, A., True, Z., Cullen, A. (2015). Environmental impacts and constraints associated with the production of major food crops in Sub-Saharan Africa and South Asia. Food Secur., 7(4): 795-822. https://doi.org/10.1007/s12571-015-0478-1

[53] Shelef, O., Weisberg, P.J., Provenza, F.D. (2017). The value of native plants and local production in an era of global agriculture. Front. Plant Sci., 8: 1-15. https://doi.org/10.3389/fpls.2017.02069

[54] Kumar, V. (2015). Role of indigenous knowledge in climate change adaptation strategies: A study with special reference to North-Western India. J. Geogr. Nat. Disasters, 5(1): 1-5. https://doi.org/10.4172/21670587.1000131 